\title{
The Affecting Factors on Employee Performance at PT PLN (Persero) Unit Pelaksana Pelayanan Pelanggan (UP3) Medan
}

\author{
Hans Andrew Simon Putra Siregar ${ }^{1}$, Iskandarini ${ }^{2}$, Nazaruddin ${ }^{2}$ \\ ${ }^{1,2}$ Master of Management Program, Postgraduate School of University of Sumatera Utara \\ Corresponding Author: Hans Andrew Simon Putra Siregar
}

\begin{abstract}
Performance is a quality result achieved by employees in performing their duties according to the responsibilities given to him. This study aims to determine: (1) the influence of communication on performances, (2) the influence of leadership on performances, (3) the influence of motivation on performances and (4) the influence of work environment on performances. The number of respondents in this study is 80 people. The analysis used in this research is regression analysis. Data were collected through questionnaires. The result of data analysis shows that there is significant influence that is motivation have positive and significant effect; work environment has a positive and significant effect on employee performance in PT PLN (Persero) Unit Pelaksana Pelayanan Pelanggan (UP3) or Customer Service Implementer Unit in Medan.
\end{abstract}

Keywords: Communication, Leadership, Motivation, Work Environment

\section{BACKGROUND}

PT PLN (Persero) is the only stateowned company engaged in electricity supply services that operates from generation, distribution to distribution throughout Indonesia. One of the performance indicators of electricity distribution services by PT PLN (Persero) to consumers is called SAIDI and SAIFI. SAIDI (System Average Interrupt Duration Index) is the duration of electricity supply disruption experienced by customers (calculated on average), while SAIFI
(System Average Interrupt Frequency Index) is the number of power supply interruptions experienced by customers (calculated on average) .

The achievements of SAIDI and SAIFI PT PLN (Persero) UP3 Medan in 2017 are still not satisfactory. One of the long duration of blackouts can be indicated as a result of the lengthy response to repairs carried out by employees / officers of PT PLN (Persero) UP3 Medan. If this condition is not resolved immediately, it will reduce the level of consumer confidence in the services of PT PLN (Persero) UP3 Medan. The company will provide optimal service if it is supported by quality resources. The resources needed by companies are also very diverse, one of which is human resources. Human resources are seen as a very important company asset because humans are a dynamic resource and are always needed in every process of producing goods and services. According to Nasution (2010) humans are a resource in the industrial and organizational fields, therefore resource management includes the provision of quality labor, maintaining quality and controlling labor costs.

Researchers conducted pre-research by conducting interviews with 30 employees of PT PLN (Persero) UP3 Medan by examining the factors that influence employee performance, namely Job Satisfaction, Leadership, Motivation, Communication, Work Environment, Training, Workload and Organizational 
Culture. From the results of the interview, it can be seen that communication is the highest factor with 20 responses. Then the second is the leadership factor as much as 17 responses. Followed by a motivational factor in the third position, namely 15 responses. And the fourth position is the work environment factor as much as 13 responses.

Table 1. Factors Affecting Employee Performanceat PT PLN (Persero) UP3 Medan

\begin{tabular}{|l|l|}
\hline Factors & Employee Response \\
\hline Job satisfaction & 7 \\
\hline Motivation & 15 \\
\hline Work environment & 13 \\
\hline Training & 11 \\
\hline Leadership & 17 \\
\hline Organizational culture & 6 \\
\hline Work Pressure / Job Stress & 4 \\
\hline Communication & 20 \\
\hline
\end{tabular}

Based on the results of the mapping of the 30 samples, the performance achievement of an employee is indicated by factors including: communication, leadership, motivation and work environment. For that it is necessary to make efforts to explore the factors that affect the performance of these employees.

\section{Communication on Employee Performance}

Effendy (2000) states that communication is the process of conveying thoughts or feelings by someone to another by using symbols that are meaningful to both parties, in certain situations communication uses certain media to change the attitude or behavior of a person or a number of people so that there are the specific effect expected. The purpose of communication is to create shared understanding or change perceptions, even behavior (Riant Nugroho, 2004). In organizations, communication is needed as a superior and a subordinate need information in relation to their respective duties and interests. Superiors communicate to convey messages through regulations and instructions to subordinates, while subordinates need communication to convey work results, ideas, suggestions, and complaints.

\section{Leadership on Employee Performance}

According to Susanto and Koesnadi (2003), a leader is a person who is determined to bring an organization to achieve its goals through a mechanism that is felt to be the most effective and according to Kartini Kartono (2005), a leader means a person who has skills and strengths, especially skills and advantages in one. fields so that he is able to influence a person or group to jointly carry out certain activities for the achievement of a purpose or goal to run effectively and efficiently.

Leadership indicators according to Pamudji (2001):

\section{Influence}

Namely a series of efforts made by a leader by demonstrating exemplary, authority, and skills to mobilize and direct subordinates to carry out their duties in order to achieve organizational goals effectively and efficiently.

\section{Information}

Namely a series of efforts made by a leader to obtain and convey news or messages either directly or indirectly to his subordinates, so that employees or subordinates can understand and be able to carry out their duties as expected in order to achieve organizational goals effectively and efficiently.

\section{Decision Making}

Is a series of efforts made by a leader in determining organizational strategy in order to achieve organizational goals effectively and efficiently, either by paying attention to suggestions from his subordinates and on his own decisions.

\section{Motivate}

Is a series of efforts made by a leader to be able to provide motives or encouragement, fulfill expectations and provide incentives to employees / subordinates so that subordinates feel 
motivated to carry out tasks sincerely, enthusiastically and happily in order to achieve organizational goals effectively and efficiently.

\section{Motivation for Employee Performance}

According to Gibson (in Warsito, 2008), individual performance is influenced by motivation, ability, and work environment factors. Motivation factors have a direct relationship with individual employee performance. Meanwhile, individual ability factors and work environment have an indirect relationship with performance. The existence of these two factors will affect employee motivation. Therefore, the position and relationship, it is very strategic if the development of individual employee performance starts from increasing work motivation.

\section{Work Environment Against Employee Performance}

The influence of the work environment is something that should not be ruled out by the company because it will have an impact on the performance of the employees which affects the company. The influence of the work environment is all things or elements that can directly or indirectly affect the organization or company that will have a good or bad impact on employee performance. (Soetjipto, 2004). The work environment is influenced by the following factors:

\section{a. Work facilities}

A work environment that does not support the implementation of work contributes to poor performance, such as a lack of work equipment, stuffy work space, inadequate ventilation, and unclear procedures.

\section{b. Salaries and allowances}

Salaries that are not in accordance with workers 'expectations will make workers look at a work environment that is more guaranteed to achieve workers' expectations.

\section{c. Work relationship}

A work group with high cohesiveness and loyalty will increase work productivity, because between one worker and another worker will support each other in achieving goals and / or results.

\section{Conceptual framework}

The conceptual framework shown in Figure 1 explains how the communication, leadership, motivation and work environment variables are related to employee performance.

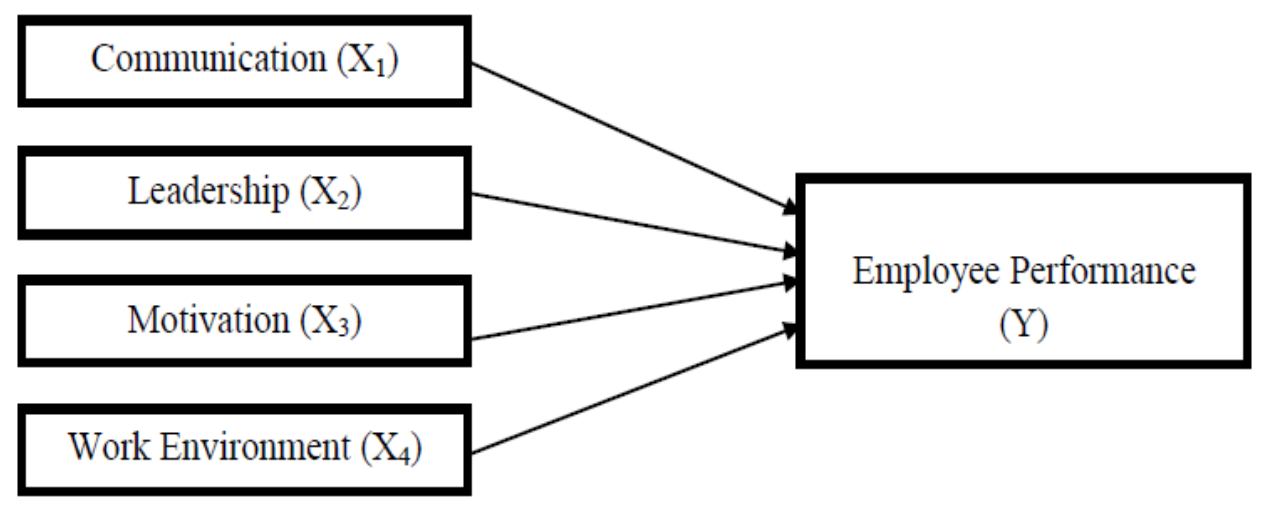

Figure 1: Conceptual framework

\section{Hypothesis}

H1: There is a positive and significant influence on the Communication factor (X1) on Employee Performance (Y).
$\mathrm{H} 2$ : There is a positive and significant influence of leadership factors (X2) on employee performance (Y). 
H3: There is a positive and significant influence on the motivation factor (X3) on employee performance (Y).

H4: There is a positive and significant influence on Work Environment (X4) on Employee Performance (Y).

H5: There is a positive and significant influence of Communication (X1), Leadership (X2), Motivation (X3) and Work Environment (X4) on Employee Performance (Y).

\section{RESEARCH METHODS}

This type of research is correlational research (Correlational Research), which is a study carried out with the aim of detecting the extent to which variations in a factor are related (correlated) with one or more other factors based on the correlation coefficient (Sinulingga, 2015). Data was collected through interviews and questionnaires, then tested individually (t-test) and simultaneously (F test) to determine whether there was an influence of communication, leadership, motivation and work environment factors on employee performance either partially or simultaneously (jointly). -same). The population in this study were employees of PT PLN (Persero) UP3 Medan who were still actively working with a total sample of 80 people.

\section{RESULTS AND DISCUSSION Analysis of the coefficient of determination}

\begin{tabular}{l} 
Table 2.Determination Coefficient Test Results \\
\begin{tabular}{|l|l|l|l|l|}
\hline Model Summary & \\
\hline Model & R & R Square & Adjusted R Square & Std. Error of the Estimate \\
\hline 1 & $.673^{\text {a }}$ & .452 & .423 & 1.90696 \\
\hline a. Predictors: (Constant), Work Environment, Communication, Motivation, Leadership \\
\hline
\end{tabular} \\
b. Dependent Variable: Employee performance \\
\hline
\end{tabular}

The test results of the coefficient of determination can be seen in Table 2. It is found that the correlation between the dependent variable and the independent variable is measured by the magnitude of the value of R and Adjusted R Square. It can be concluded as follows:

1. The correlation coefficient value is 0.673 which indicates that the correlation / relationship between the dependent variable (Y) and the independent variable (X1, X2, X3, X4) is high. If $\mathrm{R}>0.05$, the correlation is high (Sufre, 2014).

2. The coefficient of determination ( $R$ Square) is 0.452 . This means that $45.2 \%$ of employee performance is influenced by communication, leadership, motivation and work environment variables in this study. Meanwhile, the remaining $54.8 \%$ is influenced by other variables outside the independent variables used in this study.

\section{F Test Analysis}

F-test is used to determine whether the independent variables simultaneously (together) have a significant effect on the dependent variable. The degree of confidence used is 0.05 .

Table 3.ANOVA test results

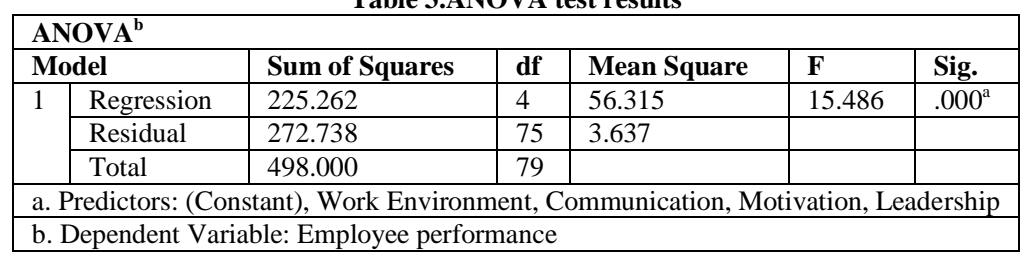

Based on the simulation results in Table 3 above, it is found that the significance value for the influence of the independent variables of communication 
(X1), leadership (X2), motivation (X3) and work environment (X4) simultaneously (together) on the dependent variable of employee performance ( $\mathrm{Y}$ ) is 0.000 ( $\mathrm{Sig}$ $<0.005)$ and the value of $\mathrm{F}$ count $=15.486$ $(>\mathrm{F}$ table $=2.49)$, so it can be concluded that there is an influence of communication (X1), leadership (X2), motivation (X3) and work environment ( X4) simultaneously on employee performance (Y).

\section{T-test analysis}

The t-test aims to determine the presence or absence of (own) partial influence given by the independent variable $(\mathrm{X})$ to the dependent variable (Y). The degree of significance used is 0.05 .

Table 4.Results of the t-test

\begin{tabular}{|l|l|l|l|l|l|l|}
\hline \multirow{2}{*}{ Model } & \multicolumn{2}{|l|}{ Unstandardized Coefficients } & Standardized Coefficients & \multirow{2}{*}{ Sig. } \\
\cline { 3 - 7 } \multicolumn{2}{|l}{} & B & Std. Error & Beta & & \\
\hline \multirow{3}{*}{1} & (Constant) & 5.809 & 1.997 & & 2.910 & .005 \\
\cline { 2 - 7 } & Communication & .041 & .109 & .049 & .378 & .707 \\
\cline { 2 - 7 } & Leadership & .114 & .076 & .187 & 1.494 & .139 \\
\cline { 2 - 7 } & Motivation & .238 & .083 & .336 & 2.857 & .006 \\
\cline { 2 - 7 } & Work Environment & .145 & .070 & .229 & 2.052 & .044 \\
\hline
\end{tabular}

Based on the simulation results in Table 3, the interpretive analysis is obtained as follows:

\section{Communication (X1) on Employee Performance (Y)}

The Sig value of the simulation result is greater than the probability value of 0.05 or the value of $0.707>0.05$, so $\mathrm{H} 1$ is rejected and $\mathrm{Ho}$ is accepted. The variable $\mathrm{X} 1$ has $\mathrm{t}$ count $=0.378$ while $\mathrm{t}$ table $=$ 1.99210. So, because t count <t table, it can be concluded that the communication variable has a positive and insignificant effect on employee performance.

\section{Leadership (X2) on Employee Performance (Y)}

The Sig value of the simulation result is greater than the probability value of 0.05 or the value of $0.139>0.05$, then $\mathrm{H} 1$ is rejected and Ho is accepted. The variable $\mathrm{X} 2$ has $\mathrm{t}$ count $=1.494$ while $\mathrm{t}$ table $=$ 1.99210. So because t count <t table, it can be concluded that the leadership variable has a positive and insignificant influence on employee performance.

\section{Motivation (X3) on Employee Performance (Y)}

The Sig value of the simulation result is smaller than the probability value of 0.05 or the value of $0.006<0.05$, then $\mathrm{H} 1$ is accepted and Ho is rejected. The variable
$\mathrm{X} 3$ has $\mathrm{t}$ count $=2.857$ while $\mathrm{t}$ table $=$ 1.99210. So because $t$ count $>t$ table, it can be concluded that motivation has a positive and significant effect on employee performance.

\section{Work Environment (X4) on Employee Performance (Y)}

The Sig value of the simulation result is smaller than the probability value of 0.05 or the value of $0.044<0.05$, then $\mathrm{H} 1$ is accepted and Ho is rejected. The variable $\mathrm{X} 4$ has $\mathrm{t}$ count $=2.052$ while $\mathrm{t}$ table $=$ 1.99210. So because $t$ count $>t$ table, it can be concluded that the work environment has a positive and significant influence on employee performance.

\section{CONCLUSION}

From the data obtained and the analysis that has been carried out in this study, it can be concluded that:

1. Simultaneously (together) the factors of leadership, communication, motivation and work environment have a significant influence on employee performance at PT PLN (Persero) UP3 Medan.

2. Partially, motivational factors and work environment have a positive and significant influence on employee performance at PT PLN (Persero) UP3 Medan. This means that the more motivation and work environment 
increases, the employee's performance will also increase.

3. Partially, communication and leadership factors have a positive and insignificant influence on employee performance at PT PLN (Persero) UP3 Medan.

\section{REFERENCES}

1. A.A Anwar Prabu Mangkunegara (2012). Manajemen Sumber Daya Manusia. Bandung: PT. Remaja Rosdakarya.

2. Ardana. 2012. Manajemen Sumber Daya Manusia. Yogyakarta: Graha Ilmu.

3. D. Riant, Nugroho. 2004. Kebijakan Publik, Formulasi Implementasi Dan Evaluasi. Jakarta: Gramedia.

4. Danang, Sunyoto. 2012. Manajemen Sumber Daya Manusia. Jakarta: PT Buku Seru. http://repository.upi.edu/17628/4/S_MBS_1 001311_Bibliography

5. Devito, Joseph A. 2011. Komunikasi Antar Manusia. Pamulang-Tangerang Selatan: Karisma Publishing Group.

6. Edy Sutrisno, 2011, Manajemen Sumber Daya Manusia, Jakarta: Kencana.

7. Effendy, Onong Uchjana. 2000, Ilmu Komunikasi dan Praktek. Bandung: PT. Remaja Rosdakarya.

8. _ 2002. Ilmu, Teori dan Filsafat Komunikasi, Bandung: PT. Citra Aditya Bakti.

9. Gomes, Fouston C. 2003. Manajemen Sumber Daya Manusia, Binarupa Aksara, Jakarta.

10. Gomes, Faustino Cardoso. 2012. Manajemen Sumber Daya Manusia. Yogyakarta: ANDI.

11. Handoko, T. Hani. 2011. Manajemen Personalia dan Sumber Daya Manusia. Yogyakarta: Penerbit BPFE.

12. Hasbullah (2011). Sistem Pendidikan Nasional. Jakarta: Rajawali Pers.

13. Hasibuan, Malayu. 2001. Manajemen Sumber Daya Manusia:Pengertian Dasar, Pengertian, dan Masalah. Jakarta: PT. Toko Gunung Agung.

14. . 2003. Manajemen Sumber Daya Manusia, Edisi Revisi, Bumi Aksara, Jakarta.

15. 2012. Manajemen Sumber Daya Manusia dan Kunci Keberhasilan. Jakarta: Haji Mas Agung.
16. Katz, D. \& Kahn, R.L. 1966. The Social Psychology of Organization. A Wiley International Edition.

17. L. Mathis, Robert - H. Jackson, John., 2011. Human Resource Management (edisi 10). Jakarta: Salemba Empat.

18. Munandar. 2010. Budgeting - Perencanaan Kerja, Pengkoordinasian Kerja, Pengawasan Kerja. Edisi Kelima. Yogyakarta: BPFE.

19. Norianggono, Hamid dan Ika Ruhana. 2014. Pengaruh Lingkungan Kerja Fisik dan Non Fisik Terhadap Kinerja Karyawan (Studi Pada Karyawan PT. Telkomsel Area III Jawa-Tengah Nusra di Surabaya).

20. Pace, R. Wayne dan Don F. Faules. 2005. Komunikasi Organisasi, Strategi Meningkatkan KInerja Perusahaan. Editor: Dedy Maulana. PT. Remaja Rosdakarya. Bandung.

21. Panuju, Redi. 2001. Komunikasi Organisasi dari Konseptual-Teoritis ke Empirik. Yogyakarta: Pustaka Pelajar.

22. Prawirosentono, Suyadi. 2002. Manajemen Sumber Daya Manusia: Kebijakan Kinerja Karyawan. Edisi 1. Cetakan Kedelapan. BPFE. Yogyakarta

23. Prawirosentono, 2012. Filosofi Baru Tentang Manajemen Mutu Terpadu Abad 21 Studi Kasus \& Analisis. Bumi Aksara, Jakarta.

24. Robbins SP, dan Judge. 2008. Perilaku Organisasi Buku 2, Jakarta: Salemba Empat.

25. 2 2011. Perilaku Organisasi, Jakarta: Salemba Empat.

26. 2007. Perilaku Organisasi, Jakarta: Salemba Empat.

27. Rogers dan Kincaid, 2005, Communication for Social Change, Mazi Article.

28. Sedarmayanti. 2008. Lingkungan Kerja. Bandung: Mandar Maju.

29. _ 2012. Manajemen dan Komponen Terkait Lainnya. Bandung: PT. Refika Aditama.

30. Soetjipto, B. W. 2004. Manajemen Sumber Daya Manusia. Yogyakarta: Penerbit Asmara Books.

31. Simanjuntak, Payaman J, 2003, Produktivitas Kerja Pengertian dan Ruang Lingkupnya, Prisma, Jakarta.

32. Sinulingga S. 2015. Metode Penelitian. Edisi 3. Medan: USU Press.

33. Suprihanto Jhon, dkk., (2003). Perilaku Organisasional. Yogyakarta: Sekolah Tinggi Ilmu Ekonomi YKPN. 
Hans Andrew Simon Putra Siregar et.al. The affecting factors on employee performance at PT PLN (Persero) Unit Pelaksana Pelayanan Pelanggan (UP3) Medan.

34. Susanto A.B; Koesnadi Kardi. 2003. Pemimpin dan Kepemimpinan. Jakarta: Grafindo Persada.

35. Tubbs, L Steward dan Moss Sylvia. 2001. Human Communication (Konteks-Konteks Komunikasi). Bandung: Remaja Rosda Karya.

36. Wiryanto. 2005. Pengantar Ilmu Komunikasi. Jakarta: PT. Gramedia Widiasarana Indonesia.
37. Vardiansyah, Dani. 2004. Pengantar Ilmu Komunikasi: Pendekatan Taksonomi Konseptual. Ghalia Indonesia, Jakarta.

How to cite this article: Hans Andrew Simon Putra Siregar, Iskandarini, Nazaruddin. The affecting factors on employee performance at PT PLN (Persero) Unit Pelaksana Pelayanan Pelanggan (UP3) Medan. International Journal of Research and Review. 2021; 8(1): 29-35. 